\title{
Infarct-related artery filled with thrombus cleared completely after tirofiban therapy
}

Rezolucja skrzepliny wypełniającej tętnicę odpowiedzialną za zawał po leczeniu tirofibanem

\author{
Serkan Bulur', Hakan Özhan'1, Yasin Türker', Şule Bulur ${ }^{2}$ \\ 1Department of Cardiology, Duzce University, Duzce Medicine Faculty, Turkey \\ 2Department of Physiology, Selcuk University, Meram, Turkey
}

Post Kardiol Interw 2012; 8, 1 (27): 75-77

DOI: $10.5114 /$ pwki.2012.28074

\begin{abstract}
The treatment of acute coronary syndrome patients with high thrombus burden is difficult. Percutaneous coronary interventions increase the frequency of distal embolization in these patients. Glycoprotein IIb/IIla inhibitors are effective anti-platelet agents and they can be very helpful in such cases. Herein, we present the impact of tirofiban infusion on an infarct-related artery with high thrombotic burden. The thrombus cleared completely without coronary angioplasty.
\end{abstract}

Key words: acute coronary syndrome, glycoprotein IIb/IIla inhibitor

\section{Streszczenie}

Leczenie ostrych zespołów wieńcowych u pacjentów, u których obecna jest duża ilość skrzeplin, jest skomplikowane. Przezskórne interwencje wieńcowe zwiększają częstość występowania dystalnej embolizacji u tych chorych. Inhibitory glikoproteiny IIb/IIla są skutecznymi lekami przeciwpłytkowymi i mogą być bardzo pomocne w takich sytuacjach. Prezentujemy wpływ wlewu tirofibanu na tętnicę odpowiedzialną za zawał wypełnioną materiałem zakrzepowym. Skrzepliny uległy całkowitej rezolucji bez konieczności wykonywania angioplastyki wieńcowej.

Słowa kluczowe: ostry zespół wieńcowy, inhibitor glikoproteiny IIb/IIla

\section{Introduction}

Coronary atherosclerosis is the most frequent cause of ischaemic heart disease, and plaque disruption with superimposed thrombosis is the main cause of acute coronary syndrome (ACS) [1]. The clinical manifestation of an ACS thrombotic event is determined by the balance between the propensity for thrombus formation and the efficacy of the endogenous thrombolytic processes [2]. An invasive strategy of coronary angiography, with revascularization when appropriate, is recommended for high-risk patients who have an acute coronary syndrome [3].

Tirofiban is a non-peptide tyrosine derivative which belongs to the class of glycoprotein (GP) Ilb/Illa inhibitors (GPI). By preventing the binding of fibrinogen and von Willebrand factor to the GP IIb/llla receptor on the surface of the platelet, GPIs are currently regarded as the most potent inhibitors of platelet aggregation [4].

Herein, we present the effect of tirofiban infusion on an infarct-related artery with high thrombotic burden.

\section{Case report}

A 73-year-old woman was admitted to our hospital with fluctuating crushing chest pain. The electrocardiogram (ECG) revealed normal sinus rhythm and negative T waves on V1-V2 and aVL. Her medical history revealed hypertension. She was taken to the catheterization laboratory for percutaneous coronary intervention with the diagnosis of acute coronary syndrome. Coronary angiography showed that the right coronary artery was filled with thrombus (Figure 1). The left anterior descending and circumflex arter-

\section{Corresponding author/Adres do korespondencji:}

Dr. Serkan Bulur, Duzce Universitesi, Düzce Tıp Fakültesi 81620, Konuralp Düzce, Turkey, tel: +90 5333863984 , fax: +90 3805414105 , e-mail: drserkanbulur@yahoo.com

Praca wpłynęta: 24.11.2011, przyjęta do druku: 30.01.2012. 


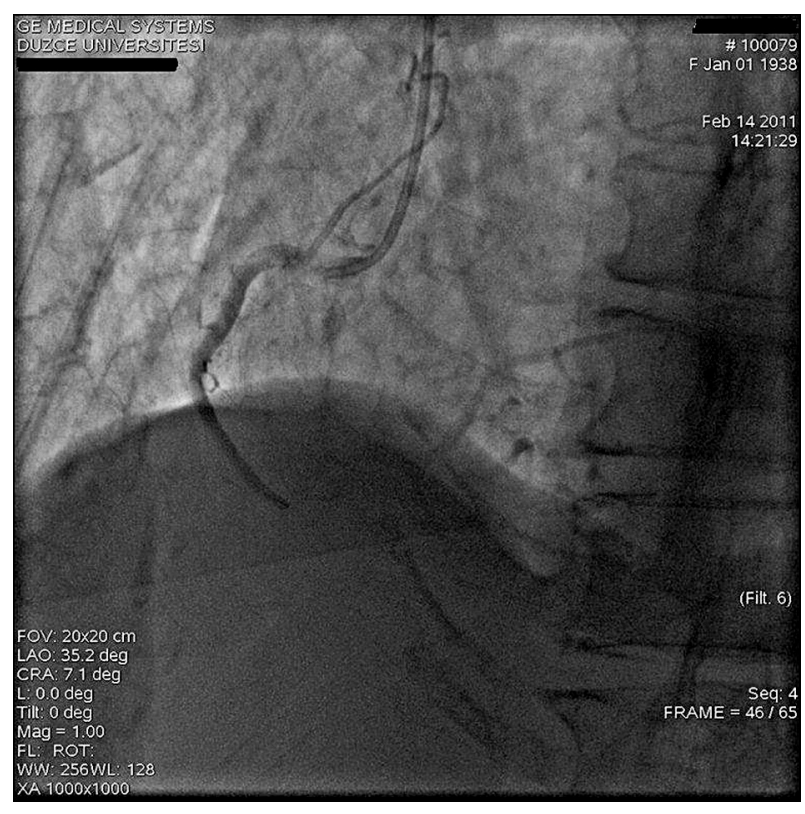

Fig. 1. Right coronary artery before tirofiban treatment

Ryc. 1. Prawa tętnica wieńcowa przed leczeniem tirofibanem

ies were normal. The culprit lesion could not be identified. Therefore, tirofiban infusion $0.40 \mu \mathrm{g} / \mathrm{kg} / \mathrm{min}$ for the first $30 \mathrm{~min}$ plus $0.10 \mu \mathrm{g} / \mathrm{kg} / \mathrm{min}$ infusion was started and continued for $48 \mathrm{~h}$. In addition, aspirin, clopidogrel and low molecular weight heparin were given for ACS therapy. At the end of the infusion, the coronary angiogram was repeated. The right coronary artery was completely cleared (Figure 2). Creatine kinase (CK), CK-MB and troponin values did not increase during hospital follow-up. The patient was symptom-free after discharge from the hospital and was doing well at her 6-month follow-up visit with aspirin $100 \mathrm{mg}$, metoprolol $50 \mathrm{mg}$, clopidogrel $75 \mathrm{mg}$, atorvastatin $10 \mathrm{mg}$ and perindopril $10 \mathrm{mg} /$ day therapy.

\section{Discussion}

The presence of angiographically detected thrombosis in patients presenting with ACS is associated with a higher incidence of in-hospital and long-term adverse cardiac events [5]. In the setting of ACS or when faced with a thrombotic lesion for which percutaneous coronary intervention $(\mathrm{PCl})$ is being considered, adjunctive pharmacological therapy delivered intravenously or via the intracoronary route should aim at the prevention of thromboembolic events associated with $\mathrm{PCl}$, and the reversal of such events if they occur. The interventional cardiologist is faced with the hard task of managing lesions with high thrombotic burden, which is more prevalent when earlier catheterization is performed [6]. The mechanical manipulation of such lesions is associated with a high incidence of periprocedural complications at least in part due to a high incidence of distal embolization [7]. Intravenous

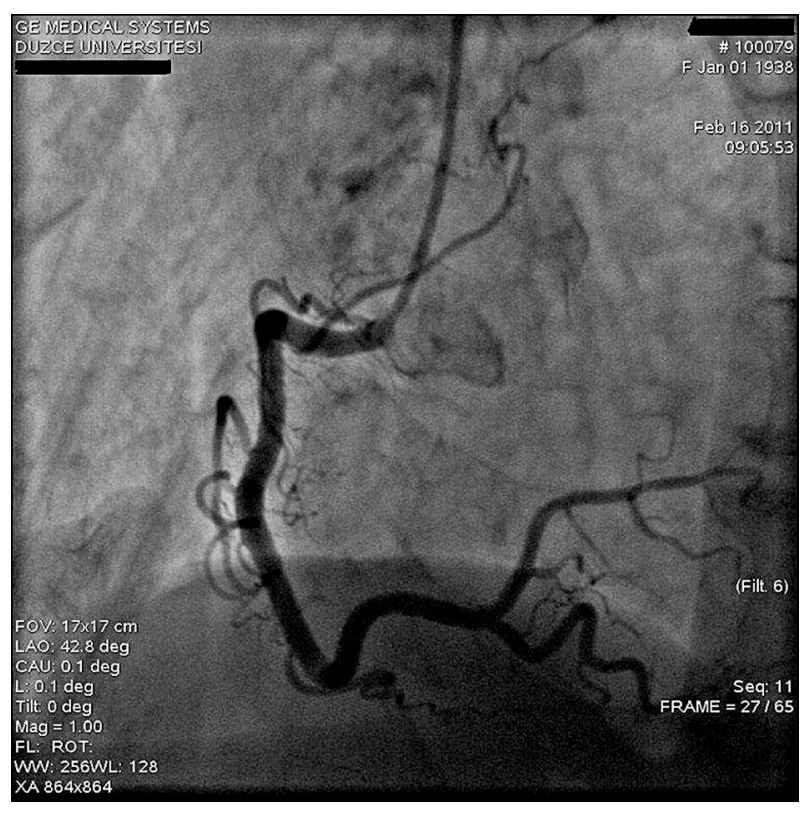

Fig. 2. Right coronary artery after tirofiban treatment

Ryc. 2. Prawa tętnica wieńcowa po leczeniu tirofibanem

antiplatelet GP IIb/IIla inhibitors are frequently administered to patients with ACS undergoing $\mathrm{PCl}$, a strategy supported by several randomized clinical trials [3]. In our index patient, $\mathrm{PCl}$ was delayed due to very high thrombus burden and mismatch of ECG changes with the coronary anatomy. However, aggressive antiplatelet treatment with tirofiban, a potent inhibitor of GP IIb/IIla receptors, in combination with low molecular weight heparin was administered. The result was a perfectly cleared coronary artery without a need for $\mathrm{PCl}$. Therefore, invasive cardiologists should always keep in mind that GP IIb/IIla receptor blockers may avoid unnecessary percutaneous coronary intervention in patients with acute coronary syndrome complicated with very high intracoronary thrombus burden. In such cases "cooling" the lesion with appropriate antithrombotic therapy may help to achieve better results and even prevent unnecessary interventional procedures.

\section{References}

1. Falk E, Shah PK, Fuster V. Coronary plaque disruption. Circulation 1995; 92: 657-671.

2. Saraf S, Christopoulos C, Salha IB, Stott DJ, Gorog DA. Impaired endogenous thrombolysis in acute coronary syndrome patients predicts cardiovascular death and nonfatal myocardial infarction. J Am Coll Cardiol 2010; 55: 2107-2115.

3. Wright RS, Anderson JL, Adams CD, et al. 2011 ACCF/AHA focused update of the guidelines for the management of patients with unstable angina/non-ST-elevation myocardial infarction (updating the 2007 guideline): a report of the American College of Cardiology Foundation/American Heart Association Task Force on Practice Guidelines. Circulation 2011; 123: 2022-2060. 
4. Topol EJ, Byzova TV, Plow EF. Platelet GPIIb-IIla blockers. Lancet 1999; 353: 227-231.

5. Freeman MR, Williams AE, Chisholm RJ, Armstrong PW. Intracoronary thrombus and complex morphology in unstable angina. Relation to timing of angiography and in-hospital cardiac events. Circulation 1989; 80: 17-23.

6. Matar F, Mroue J. The management of thrombotic lesions in the cardiac catheterization laboratory. J Cardiovasc Transl Res 2011; Oct 21.

7. Henriques JP, Zijlstra F, Ottervanger JP, et al. Incidence and clinical significance of distal embolization during primary angioplasty for acute myocardial infarction. Eur Heart J 2002; 23: 1112-1117. 